
\title{
$\left.\mathbf{E}\right|_{\text {uropean }} \mathbf{A}$ cademy of $\mathbf{N}$ utritional $\mathbf{S}_{\text {ciences }}$ uropean Academy of $\mathbf{N}$ utritional $\mathbf{S}$ ciences r 卖

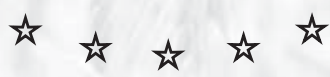 \\ EANS Society News
}

\section{EANS Officials 2004 (Interim)}

\section{President:}

Prof. Ibrahim Elmadfa

Vice-Presidents:

Prof. P.J. Aggett

Prof. Carlo Agostoni

Dr. Carmen Pérez Rodrigo

\section{Secretary General:}

Dr. Jean-Michel Antoine

\section{Treasurer:}

Dr. Pierre Guesry

\section{Website Committee:}

Prof. Dr. P.J. Aggett

\section{Website:}

www.eans.net

\section{EANS Secretariat:}

E-mail: info@eans.net

\section{Mission}

EANS is an association of individual nutritional scientists sharing the following aims:

- to be the custodian of the quality of the European nutritional science

- to support the high quality education of young nutritional scientists

- to create a platform for discussing, summarizing and communicating important nutritional issues

\section{To achieve these aims EANS will:}

- encourage and support the organization of high quality symposia and workshops within Europe. EANS patronage is a mark of quality

- encourage and support its members to play an active role in public debates on nutrition

- encourage its members to be active in training programmes for young scientists, both in scientific and communicative fields

The strength of EANS is the quality of its members. The membership selection procedures ensure, that this will remain so.

\section{Membership}

EANS Secretariat

Dr. Jean-Michel Antoine

Interfaces Scientifiques

Nutrivaleur

Route Départementale 128

F-91767 Palaiseau Cedex (France)

E-Mail jean-michel.antoine@danone.com 